\section{Evaluating Building Sustainability Literacy Level in Nigerian Architectural Education}

\section{Oluseyi A. Olagoke*}

Mustards Architectural Concept, Oshogbo, Nigeria

\section{Olusola O. Bamisile}

Cyprus International University, Nicosia

*Corresponding author: olagokeseyi@yahoo.com

\section{$\Gamma$} crossef http://dx.doi.org/10.5755/j01.sace.21.4.18620

Sustainability has become a qualifying factor in every human endeavor and architectural educators could really not care less in ensuring a holistic education premised on the tenets of both conscientious and discretionary use of the ever-depleting natural resources much of which is morally right to be left for yet many future generations. Also, since a good proportion of architecture graduates from Nigerian tertiary institutions end up as teachers in architecture departments, it becomes important to understand the level of their knowledge of the concept of building sustainability while in school as understanding this could be helpful in positioning them to be better architectural educators.

This research hence focuses on six selected departments of architecture and architectural technologies in tertiary institutions in southwest Nigeria and the aim is to establish whether the concept of sustainability is well taught and understood both by architectural educators and students. Open and close-ended questionnaires were distributed to students and the results are analyzed using statistical tools. Consequently, findings derived from this survey are hoped to help inform a set of recommendations aimed at enhancing improved knowledge acquisition by these teaming future professionals thus ensuring a holistic and balanced training and education necessary for proper entrenchment of the much needed sustainability consciousness and awareness in Nigeria.

Keywords: architectural education, building sustainability, literacy level, Southwest Nigeria.

If the principles of a sustainable environment are to be well entrenched, the role of educational institutions cannot be downplayed but it is a general opinion that there is no definite framework to foster this in architecture curricula. Less can surely be said of other "related" departments in Nigerian schools of higher learning (Shari and Mohd, 2006). So, examining the content of the current curriculum and enforcing necessary alterations as the tenets of building sustainability will require (in the context of Nigeria's geographical peculiarities) is itself needful (James 2003). Responsible and well informed designers are the only select few that possess both the competency and initiatives to deliver responsible designs and it is only logical to assert that such knowledge could mostly be gotten from academic institutions and environments - sometimes also as apprentice to well-established professionals. Roles of architects in managing environmental degradations, deforestation, climate change, waste management and other means of natural resources exhaustion cannot be over-emphasized; but it quietly becomes worrisome if and when these individuals
JSACE $4 / 21$

Evaluating Building Sustainability Literacy Level in Nigerian Architectural Education

Received 2017/09/04

Accepted after revision 2017/12/29

\section{Introduction}

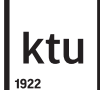

Journal of Sustainable Architecture and Civil Engineering Vol. 4 / No. 21 / 2017 pp. $23-28$ DOI 10.5755/j01.sace.21.4.18620 (c) Kaunas University of Technology 
are grossly incapacitated both by inadequate training and lack of necessary exposures. This is the current situation in Southwest Nigeria where rapid physical infrastructural and developmental activities are currently ongoing.

This research aims to ascertain the omission of architectural sustainability knowledge and awareness level as indicated in the taught curriculum of architectural education in Nigeria's tertiary institutions.

Justification of Study Location and Research Methodology
According to the Joint Admissions and Matriculation Boards (JAMB, 2017) - the government agency saddled with the responsibility of regulating the process of admitting students to tertiary institutions in Nigeria, - there currently are thirty-six polytechnics and thirty-five universities offering architecture or architectural technology as the case may be in the country. Of these, twelve polytechnics (i.e. 33.3\%) and eleven universities (i.e. 31.4\%) are located in the six south-western states of Ekiti, Lagos, Ogun, Ondo, Osun, and Oyo. This, invariably, is the geo-political region with the highest concentration of institutions offering architecture degrees in all of the country hence making it an ideal location to survey sustainability literacy level among its current architecture students. Also, according to M. Adegbile (2012), the highest concentration of registered architects in Nigeria, is in Lagos, the commercial capital of Nigeria. So, the set of states in this region are arguably at the most risk of adverse environmental set-backs if a bulk of these architecture graduates prove to be incompetent in handling issues germane to general sustainability principles such as is happening in most part of the developed world. Of the said number of institutions, three universities and three polytechnics were surveyed in 2017 with responses from 139 students. The six institutions which include Ladoke Akintola University of Technology, Federal University of Technology, Akure, Obafemi Awolowo University, Federal Polytechnic, Ede, Moshood Abiola Polytechnic, and Osun State College of Technology spread across Oyo, Osun and Ondo states. These schools were chosen because they were among those in session between May and June when the questionnaires were sent out; only undergraduate students from year one to year four were assessed.

The preferred methodology used for this research is quantitative quasi-experimental (Groat and Wang, 2002). Questionnaires were distributed both to both male and female students in order to determine, assess and evaluate their level of understanding and also to identify their concept of building sustainability; added to this random semi-structured elite interviews were carried out. Further evaluations of all relevant assessments are analyzed and these all combine to inform carefully made recommendations and conclusion.

\section{Environmental Literacy and Architectural Mediocrity}

We would describe architectural mediocrity as the state of lack of mental alertness and creativity by architects and that often pre-disposes them to performing below expectations in their professional practice. Since sustainable design safely describes as providing housing and building solutions that have little or no adverse impact on the very localized environment, it thus becomes imperative to pay attention to understanding the environment and how best to manage its resources and here comes in the essence of environmental literacy. M. Adegbile (2012) explained the drabness and apparent lack of architectural sustainability content in the core of the study curricula of architecture departments in all of Nigerian institutions. He attributed this to the lack of willingness to make an appraisal of how the not-too-distant past iconic traditional pre-colonial architecture thrived in our environmental context and how post-colonial architecture on the other hand seemingly has got no regard for our geography.

Environmental awareness predates environmental responsiveness and these both begot environmental sustainability. So, exclusive consideration for just animate objects will not only be unfair but also ill-intentioned in the quest for any society to be environmentally responsive. This makes 
both long and short term decisions that adequately consider the wellbeing of other environmental entities like sun, rivers, air and sky as such very desirable. Also, in a geo-political setting where there are palpable missing links in policy formation and implementation, individuals are often left to the use of subjective and simple discretions in their modus operandi; this is obviously short of best practice as it will be an upheaval task to dare single-handedly or at best impulsively spearhead a principle that directly challenges established status quo (Gardner and Stern, 2002). This inertia is hard to overcome! In Nigeria, relevant organizations and governmental agencies whose oversight include managements, registration and accreditation of universities' and polytechnics' courses are rather implored to take responsibility for including active sustainability components into building construction-related courses and especially architecture.

\section{Understanding the Concept of Building Sustainability in Nigeria}

Currently, improvement on physical infrastructure and building is a major concern to all developing countries (Bardhan and Mookherjee, 2006) such as Nigeria (Ibrahim, 2016) as a result of its understandable rapid rate of population growth; it is then of serious concern how the country goes about meeting this need in view of the current arguably weak policies on green building and sustainability. Beyond formulating policies, incorporation of holistic frameworks hinged upon localized and relevant best practices rather than importing such from other societies would be desirable.

Replicating great construction progresses made globally is undoubtedly ideal as it is a goal of building practitioners in Nigeria which is typical of all emerging countries; but the possibility of achieving this any time soon in a sustainable manner is perhaps non-existent as a result of some of the factors earlier mentioned such as weak government institutions, dearth of expertise and unfavorable regulatory framework (Othman, 2013). Whereas addressing these issues is quite as multi-faceted as the problems itself, yet, ascertaining the perceived environmental awareness of architecture students of building sustainability and sustainable construction in itself is as vital as other approaches.

There is still much to be understood especially with the current lack of a cohesive understanding in the definition of building sustainability as seen in the problem statement. When there is no consensus on a problem definition, divergent approaches in solving such overwhelming related problems are inevitable; unfortunately, there will be little or no results to show for whatever effort is channeled without a concise sense of direction.

\section{Impact of Current Living Conditions on Students' Sustainability Awareness}

There is no over-flogging the long established thought that suggests the impact that our environment has in forming our worldview and intricate opinion on issues of equal concern to others. This survey equally takes a dive into understanding if the current accommodation of all responders has ever endeared them to thinking green. Building climatology and building physics, orientation, natural lighting and natural ventilation are instinctively elementary elements of green design that most architecture students are at least expected to be familiar with and their responses show how divergent their understandings on this are. Similarly, the non-enforcement of building codes that stipulate minimum requirements for sustainable building elements is obviously missing in both state and local building planning regulations in most parts of Nigeria: this then calls for concern as many of the respondents already resumed the process of 'semi-professional' indoctrination while in school. So, coupled with the fact that almost nothing in their current built environment is strong enough to sensitize them on building sustainability, the building practices they are already exposed to in the early and formative stage of their professional career is also grossly deficient (Ajah and Isaiah, 2016). Therefore, if this is not holistically looked into, this undesired trend will simply continue.

As an environmental factor that will refuse to be waived off, of paramount and equal importance then is understanding the disposition of (potential) clients to building sustainability and green 
architecture. Interestingly, the simple logic of a repeated cycle plays itself out here: there are no green buildings around; architects are ignorant of its concept and principles; there are no regulations insisting of green components to be included in any proposed building design and then there are no clients interested in environmental sustainability. So, very important is understanding which one comes first and overcoming the inertia in addressing the others. Its ironical to realize one obvious palpable reason for the seeming lack of interest by building designers to use sustainable building elements (which are usually locally-sourced building materials); the usual preference is for contemporary building materials which generally are not locally produced and hence contribute in no little way to environmental pollution directly or indirectly because of their non-reusability and non-recyclability. The usual justification for this is rather merely premised on the fact that it shows improved societal status.

Whereas the essence of sustainable building includes the usage of traditional building materials, current building trends in the developed world can still be of huge relevance provided local architects understand how best to incorporate these to produce sustainable results. In doing this, understanding efficient waste and water management, energy efficiency, the relevance of green roof and rain gardens alongside conscious awareness of building climatology cannot be over-emphasized (Ajah and Isaiah, 2016).

\begin{tabular}{|c|c|c|c|c|}
\hline Table 1 & \multirow{2}{*}{ Questions } & \multicolumn{3}{|c|}{ Percentage } \\
\hline \multirow{12}{*}{$\begin{array}{l}\text { Overview of } \\
\text { responses from } \\
\text { the respondents }\end{array}$} & & Yes & No & Not Sure \\
\hline & 1. Are you aware of the concept/principles of building sustainability? & 74.7 & 11.3 & 14.0 \\
\hline & $\begin{array}{l}\text { 2. Are there perceived elements of building sustainability in the physical } \\
\text { infrastructure of your school? }\end{array}$ & 52.7 & 24.0 & 23.3 \\
\hline & $\begin{array}{l}\text { 3. Are there elements of building sustainability in the architectural } \\
\text { curriculum of your school? }\end{array}$ & 71.3 & 14.7 & 14.0 \\
\hline & $\begin{array}{l}\text { 4. With regards to your studio design courses, do you attempt to } \\
\text { incorporate the elements/principles of building sustainability into your } \\
\text { works? }\end{array}$ & 80.0 & 9.3 & 10.7 \\
\hline & $\begin{array}{l}\text { 5. As an architect, do you incorporate the principles of building } \\
\text { sustainability into your design projects? }\end{array}$ & 56.7 & 35.3 & 8.0 \\
\hline & $\begin{array}{l}\text { 6. Since environmental literacy and sustainability literacy can be difficult } \\
\text { to separate, could you then say that your personal knowledge of our } \\
\text { environment suggests an urgent need to conserve all natural resources? }\end{array}$ & 72.7 & 4.0 & 23.3 \\
\hline & 7. Have you been offered any sustainability course in your school? & 69.3 & 30.7 & - \\
\hline & $\begin{array}{l}\text { 8. Could you assert that your current residence has a direct influence on } \\
\text { your perception of building sustainability? }\end{array}$ & 38.0 & 30.7 & 31.3 \\
\hline & 9. Are you personally concerned about building sustainability? & 86.0 & 8.7 & 5.3 \\
\hline & $\begin{array}{l}\text { 10. Will you recommend that more courses on building sustainability be } \\
\text { introduced into architecture curriculum? }\end{array}$ & 84.7 & 11.3 & 4.0 \\
\hline & $\begin{array}{l}\text { 11. How will you rate the level of sustainability and environmental } \\
\text { literacy level in your institution? }\end{array}$ & $\begin{array}{l}\text { Average } \\
14.0\end{array}$ & $\begin{array}{l}\text { Above } \\
\text { Average } \\
72.0\end{array}$ & $\begin{array}{l}\text { Below } \\
\text { Average } \\
14.0\end{array}$ \\
\hline
\end{tabular}

\section{Assessing Current Sustainability Awareness Level of Nigerian Architecture Students}

Surprisingly, the apparent danger of misconception is a formidable force worth giving some attention it deserves as realized quite recently. It is pathetic that a good number of architecture students (78.2\%) opined that they understand what building sustainability is but failed to justify this position when probed further. A staggering $23.3 \%$ remain indifferent as to the urgency of learning 
more improved mechanisms of better enhancing environmental literacy level. This again raises some further concerns that highly question the intellectual integrity of their tutors on one side and also that of the validity and continued relevance of architecture curriculum. Curiously, $13.5 \%$ of the respondents insist that environmental and sustainability literacy level in their schools is much below average thus leaving much to be desired. In fact, many (i.e. 27.6\%) admitted have never been offered any building sustainability course. It is relieving however learning that $90.1 \%$ of the respondents recommend that more building sustainability courses be introduced into the architecture curriculum if Nigeria will ever stand shoulder-to-shoulder with other environment-conscious developed and developing countries.

As the case currently is, the challenge or desire to invent creative means of solving environmental problems through responsive building designs is conspicuously missing as half-baked architects may end up causing more damage instead; this again is evident in the $29.2 \%$ of the surveyed student admitting their lack of motivation in incorporating the rather uninteresting sustainable elements taught into their design projects. Worse still, a fair percentage of them (i.e. 30.7\%) are not sure whether their course contents are in any way tailored towards environmental and building sustainability.

Except the needful is done, the challenges of architectural and building sustainability will soon become unbearable and a majority of the locally trained architects will unfortunately not be able to meet up with these expectations. This becomes yet more worrisome as the role of the professionals in the built environment in ensuring that Nigeria meets her long-term developmental goals cannot be achieved.

The assertion of A. O. Olutuah and O. S. Adesiji (2005) that "the programmes of schools of architecture in Nigeria lead to the production of professionals who are sensitive to human needs and aspirations and who have the requisite knowledge and the intellectual and aesthetic skills to evolve expressive design solutions of problems of the built environment" is thus rather arguable for reasons of subjectiveness. It is perhaps easier to believe that sustainability-conscious Nigerian architecture graduates are rather self-taught than being a direct product of the architecture curricula of Nigerian schools of architecture.

Ignoring the reality of green architecture in any given geography means endangering the future of the built environment of such place. There is neither gainsaying nor over-emphasizing the need to address sustainability deficiencies in Nigerian architectural education and practice (Adeyemi, 2000; Uji, 2001; Dare-Abel, 2015). This is directly related to the content of the prevailing teaching curriculum in our architecture schools. Policy formation and implementation, project monitoring, funding and training and retraining are all key components to work upon in order to sufficiently initiate robust and exhaustive sustainable development innovations (SDI) in Nigeria. Once properly looked into, regardless of the shortage of professional architects in the country, the role of architectural technicians and draughtsmen who themselves pose viable threats to school-trained architects and architectural technologists will also be adequately defined.

Whereas traditional architecture is a lot sustainable, the reluctance to allow prevailing international norms and standards to partly suggest a remodeling of Nigeria's architecture curriculum from its pre-independence philosophies leaves much to be desired. In ameliorating this dilemma, the need for pilot projects can also not be over-emphasized as it helps in understanding the peculiarities of the Nigerian environment. It is also observed that the National Universities Commission and the National Board for Technical Education both are the sole bodies that formulate and regulate the curricula of universities and polytechnics respectively; so, well-tailored refresher courses aimed at exposing the relevant architecture experts and consultants to current trend in sustainability principles, theories and practices will be highly desired. 
It is also recommended that the concept of passive solar designs be encouraged as this has been proven to be environmentally friendly and ultimately sustainable. Also, natural lighting and ventilation, incorporation of energy saving devices, usage of naturally occurring building materials in building design and construction should be re-emphasized.

\section{References}

Adegbile M. Nigerian Architectural Education in a Sustainable Age. Sustainable Futures: Architecture and Urbanism in the Global South. Kampala, Uganda; 2012.

Adeyemi E. A. Lest We Forget. Keynote Address to the 7th Annual General Meeting. National Workshop of the AARCHES, 24-27 February 2000.

Federal University of Technology. Akure; 2000.

Ajah E. O, Isaiah D. O. The Awareness of Sustainability Principles in the Practice of Architecture in the Developing World: a Survey of South-South Nigeria. Journal of Sustainable Development, 2016; 204-211.

Bardhan P., Mookherjee D. Decentralization and Accountability in Infrastructure Delivery in Developing Countries. The Economic Journal, 2006; 116: 101-127. https://doi.org/10.1111/j.14680297.2006.01049.x

Dare-Abel O. A. Pathways to Architecture Education and Practice Success in Nigeria. Journal of Education and Practice, 2015; 4(6): 169-175.

Gardner, G.T.,Stern, P.C.. Environmental Problems and Human Behavior (2nd ed.). Boston, M. A. Pearson Custom Publishing; 2002.

Groat L. N., Wang D. Architectural Research Methods. New York: J. Wiley; 2002, p 176.

Ibrahim M. Factors Contributing to Poor Perfor- mance in Construction Projects: Studies of Saudi Arabia. Australian Journal of Multi-Disciplinary Engineering, 2016; 1(12): 27-38.

Joint Admissions and Matriculations Board (JAMB). Brochure, 2017. (accessed 09 July 2017) Available at: http://www.jamb.gov.ng/brochure.aspx.

Olotuah, A. O., Adesiji, O. S. Housing Poverty, Slum Formation, and Deviant Behavior. Papers and Presentations, The Housing Studies Association Conference, University of Lincoln, Lincoln, UK, 8-9 September, 2005. (accessed 09 July 2017) Available at:www.lincoln.ac.uk/home/conferences/details/ has /PAPEROLOTUAH.doc.

Othman A. A. E. Challenges of Mega Construction Projects in Developing Countries. Organization, Technology \& Management in Construction: An International Journal, 2013; 1(5): 730-746. https:// doi.org/10.5592/otmcj.2013.1.10

Shari Z., Mohd F. K. J. Towards a More Sustainable Architecture Education in Malaysia. Journal of Tropical Design Research and Practice, 2006; 1(1): 57-64.

Uji A. Z. 2001. Beyond the Critiques of the Curriculum of Architectural Education in Nigeria. In U. 0. Nkwogu (Ed.) Architects and Architecture in Nigeria - A Tribute to Prof. E. A. Adeyemi. Akure: AARCHES, Shalom Publishers; 2001, pp. 109-122.

\section{About the} authors
OLUSEYI A. OLAGOKE

Architect

Mustards Architectural Concept

Main Research Area

Architectural Conservation and Building Sustainability

Address

Zone G/\#18, Adesoji Aderemi By-Pass, Oshogbo, Nigeria

Tel. +234 7037000434

E-mail: olagokeseyi@yahoo.com, oaolagoke@mustarc.com.ng

\section{OLUSOLA 0. BAMISILE}

Research Assistant

Common Courses Unit

Cyprus International University, Nicosia

\section{Address}

Tel. +905488488648

E-mail: boomfem@gmail.com 